\title{
A NEW RED-FLOWERED SALVIA (LAMIACEAE) FROM BAJA VERAPAZ, GUATEMALA
}

\author{
B.L. Turner \\ Department of Botany, University of Texas, Austin, Texas 78713 U.S.A.
}

\begin{abstract}
A new red-flowered species of Salvia is described and illustrated from the Dept. of Baja Verapaz, Guatemala: S. verapazana B.L. Turner, spec. nov. It relates to $S$. subrubens, but is distinguished by its nearly glabrous smaller leaves and included stamens.
\end{abstract}

KEY WORDS: Lamiaceae, Salvia, Guatemala, systematics

Standley \& Williams (1973), largely following Epling (1939), recognized thirteen red-flowered Salvia species as occurring in Guatemala. These workers unaccountably excluded $S$. erythrostephana Epling from their treatment, although I take this to be a "good" species; in addition to the type (UC!), recent collections have been made in Baja Verapaz by Contreras 11229, (LL).

Counting Salvia erythrostephana, the present description brings the number of redflowered Guatemalan species to fifteen.

SALVIA VERAPAZANA B.L. Turner, spec. nov. Figure 1. TYPE: GUATEMALA. Baja Verapaz: "Union Barrios, in high forest", 10 Mar 1972, Elias Contreras 11224 (HOLOTYPE: LL!; Isotype: LL!).

Similis $S$. subrubenti Epling sed habens folia parviora $3-5 \mathrm{~cm}$ longa (vice 6-12 cm longa), caules superos dense glandulosos-pubescentes (vice hispidulorum), et stamina inclusa (vice breviter exsertorum).

Perennial (?) herb to $50 \mathrm{~cm}$ high or more. Midstems sparsely pubescent to glabrate, below the inflorescence the stems are densely glandular-pubescent with spreading trichomes ca. $1.5 \mathrm{~mm}$ long, devoid of branched hairs. Midstem leaves 5-6 cm long, 2.5-3.5 cm wide, glabrous throughout or nearly so; petioles $1-2 \mathrm{~cm}$ long; blades ovate to subcordate, somewhat bicolored, the upper surfaces drying darker and 


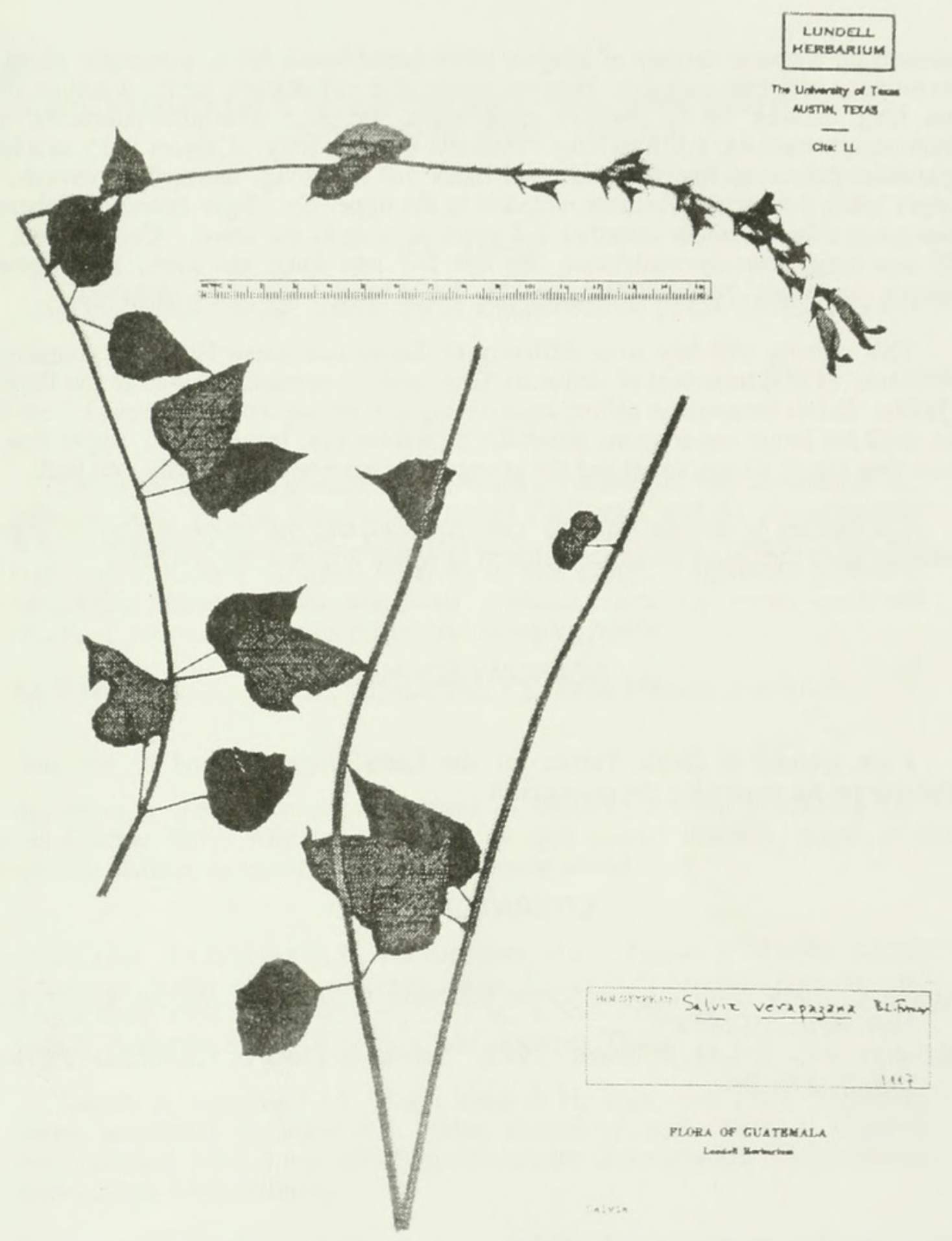

Figure 1. Salvia verapazana, from holotype. 
possessing a sparse display of simple, often broad-based hairs, especially along the serrulate to crenulate margins. Flowers arranged in rather loose terminal spikes 10-20 $\mathrm{cm}$ long, having 10-12 flowers at a node, the axis glandular-pubescent with multiseptate hairs ca. $1.5 \mathrm{~mm}$ long. Pedicels 4-6 mm long. Calyces 9-15 mm long, glandular-pubescent like the stem, the lobes $4-8 \mathrm{~mm}$ long, markedly attenuate, the upper lobes 7-nervate. Anthers included in the upper lip. Style branches pubescent along one side, the upper branches 2-3 times as long as the lower. Corollas red, 20$26 \mathrm{~mm}$ long, scarcely ventricose, the lips 5-7 mm long, the lower lip somewhat longer, rarely not. Nutlets (immature) ca. $2 \mathrm{~mm}$ long, $1 \mathrm{~mm}$ wide, glabrous.

This novelty will key with difficulty to Salvia subrubens Epling in Standley \& Williams' (1973) treatment of Salvia for Guatemala, a species endemic to the Dept. of Quiche. Salvia verapazana differs from the latter in having smaller leaves $(3-5 \mathrm{~cm}$ long vs. $6-12 \mathrm{~cm}$ long), upper stems glandular-pubescent (vs. hispidulous), upper lips 5-7 mm long (vs. 9-10 mm long) and the stamens not exserted (vs. shortly exserted).

The species is known only by type material and the name is derived from a shortening of the Guatemalan Department to which it is possibly confined.

\section{ACKNOWLEDGMENTS}

I am grateful to Gayle Turner for the Latin diagnosis, and to her and Ted Delevoryas for reviewing the manuscript.

\section{LITERATURE CITED}

Epling, C. 1939. A revision of Salvia, subgenus Calosphace. Feddes Repert. Spec. Nov. Beih. 110:1-388.

Standley, P.C. \& L.O. Williams. 1973. Salvia, in Flora of Guatemala, Fieldiana: Bot. 24:273-301. 


\section{$2 \mathrm{BHL}$ Biodiversity Heritage Library}

Turner, B. L. 1996. "A new red-flowered Salvia (Lamiaceae) from Baja Verapaz, Guatemala." Phytologia 81, 340-342. https://doi.org/10.5962/bhl.part.17985.

View This Item Online: $\underline{\text { https://www.biodiversitylibrary.org/item/46902 }}$

DOI: https://doi.org/10.5962/bhl.part.17985

Permalink: https://www.biodiversitylibrary.org/partpdf/17985

\section{Holding Institution}

New York Botanical Garden, LuEsther T. Mertz Library

\section{Sponsored by}

The LuEsther T Mertz Library, the New York Botanical Garden

\section{Copyright \& Reuse}

Copyright Status: In copyright. Digitized with the permission of the rights holder.

Rights Holder: Phytologia

License: http://creativecommons.org/licenses/by-nc-sa/3.0/

Rights: https://biodiversitylibrary.org/permissions

This document was created from content at the Biodiversity Heritage Library, the world's largest open access digital library for biodiversity literature and archives. Visit BHL at https://www.biodiversitylibrary.org. 